\title{
KERJA SAMA HUBUNGAN MASYARAKAT SDN 6 BUKIT TUNGGAL DENGAN DINAS LINGKUNGAN HIDUP KOTA PALANGKA RAYA
}

\author{
Neneng Ariska*, Teti Berliani, Sogi Hermanto \\ Universitas Palangka Raya \\ E-mail: riskar501@gmail.com
}

\begin{abstract}
Abstrak: Penelitian ini menggunakan pendekatan kualitatif dengan rancangan studi kasus. Tujuan penelitian ini adalah untuk mengetahui bagaimana perencanaan, pelaksanaan, dan pengawasan dalam menjalankan kerjsaama hubungan masyarakat pada SD Negeri 6 Bukti Tunggal dengan Badan lingkungan hidup kota Palangka Raya. Aspek yang diteliti mengacu pada: (1) Perencanaan Kerja Sama Hubungan Masyarakat Sekolah Dasar Negeri 6 Bukit Tunggal Dengan Dinas Lingkungan Hidup Kota Palangka Raya, (2) Pelaksanaan Kerja Sama Hubungan Masyarakat Sekolah Dasar Negeri 6 Bukit Tunggal Dengan Dinas Lingkungan Hidup Kota Palangka Raya, dan (3) Pengawasan Kerja Sama Hubungan Masyarakat Sekolah Dasar Negeri 6 Bukit Tunggal Dengan Dinas Lingkungan Hidup Kota Palangka Raya. Prosedur pengumpulan data yang digunakan adalah observasi, wawancara, dan dokumentasi. Kemudian data dianalisis menggunakan reduksi data, penyajian data, dan menarik kesimpulan. Sedangkan untuk pengecekan keabsahan data menggunakan kredibilitas dan konfirmabilitas. Tahap-tahap penelitian yaitu meliputi pralapangan, pekerjaan lapangan, dan analisis data. Hasil penelitian menunjukan bahwa kerja sama hubungan masyarakat yang meliputi: perencanaan, pelaksanaan, dan pengawasan, sudah dikelola dengan baik oleh SD Negeri 6 Bukit Tunggal, sehingga dapat meningkatkan produktivitas sekolah, yang akan berpengaruh positif bagi kemajuan sekolah.
\end{abstract}

Kata Kunci: Kerja Sama Hubungan Masyarakat.

\begin{abstract}
This research uses a qualitative approach with a case study design. The purpose of this study was to determine how the planning, implementation, and supervision in carrying out community relations cooperation in SD Negeri 6 Tunggal Tunggal with the Palangka Raya environmental agency. The aspects studied refer to: (1) Planning for Public Relations Cooperation between the State Elementary School 6 Bukit Tunggal with the Environmental Office of Palangka Raya City, (2) Implementation of the Public Relations Cooperation of the State Primary School 6 Bukit Tunggal with the Environmental Service Office of Palangka Raya City, dan (3) Supervision of Cooperation Public Relations of the 6 Bukit Tunggal Public Elementary School and the Environmental Office of Palangka Raya City. Data collection procedures used are observation, interviews, and documentation. Then the data are analyzed using data reduction, data presentation, and drawing conclusions. As for checking the validity of the data using credibility and confirmation. The stages of the research include pre-field, field work, and data analysis. The results showed that community relations cooperation which includes: planning, implementation, and supervision, has been well managed by SD Negeri 6 Bukit Tunggal, so as to increase school productivity, which will have a positive effect on school progress.
\end{abstract}

Keywords: Public Relations Cooperation.

\section{PENDAHULUAN}

Sekolah sebagai lembaga sosial yang tidak dapat dipisahkan dari masyarakat lingkungannya, sebaliknya masyarakatpun tidak dapat dipisahkan dari sekolah. Dikatakan demikian, karena keduanya memiliki kepentingan, sekolah merupakan lembaga formal yang diserahi mandat untuk mendidik, melatih dan membimbing generasi muda, sementara masyarakat merupakan pengguna jasa pendidikan. Secara sederhana konsep hubungan sekolah dengan masyarakat tercantum dalam Undang-undang No. 20 tahun 2003 tentang Sistem Pendidikan Nasional Pasal 54 ayat 1 dan ayat 2 menyatakan bahwa: "(1) Peran serta masyarakat dalam pendidikan meliputi peran serta perseorangan, kelompok, keluarga, organisasi profesi, pengusaha, dan organisasi kemasyarakatan dalam penyelenggaraan dan pengendalian mutu pelayanan pendidikan, dan Masyarakat dapat berperan serta sebagai 
sumber, pelaksana, dan pengguna hasil pendidikan." (UU No 20 Tahun 2003 Bab XV Pasal 54).

Berdasarkan peraturan perundangundangan di atas, hubungan sekolah dengan masyarakat merupakan hubungan timbal balik yang sinergis dan akan memberikan manfaat bagi kedua belah pihak, dimana hubungan tersebut bersifat sukarela berdasarkan keyakinan dan kesadaran, bahwa sekolah merupakan bagian integral dari masyarakat. Dalam Peraturan Pemerintah No 19 tahun 2005 Pasal 52 Ayat 1 Point h dinyatakan "setiap satuan pendidikan harus memiliki pedoman yang mengatur tentang kode etik hubungan antara sesama warga di dalam lingkungan satuan pendidikan dan hubungan antara warga satuan pendidikan dengan masyarakat". Dengan adanya hubungan tersebut diharapkan tumbuhnya kreatifitas dan dinamika kedua belah pihak, sehingga hubungan itu bersifat aktif dinamis. Hal ini memungkinkan sifat keterbukaan masyarakat terhadap inovasi. Ismaya (2015:158) mengungkapkan bahwa "Hubungan masyarakat merupakan kegiatan manajemen dalam menciptakan hubungan yang harmonis antara suatu lembaga dengan masyarakat".

SDN 6 Bukit Tunggal merupakan salah satu sekolah dasar negeri yang ada di kota Palangka Raya. keadaan awal lingkungan sekolah yaitu masih kurang kesadaran akan kebersihan lingkungan sekitar. Sekolah sudah berupaya untuk mengatasi hal tersebut, tetapi masih belum mendapatkan hasil yang maksimal. Maka dari itu untuk mengatasi kendala-kendala SDN 6 Bukit Tunggal dibantu oleh SDN Percobaan dan Dinas Lingkungan Hidup Kota Palangka Raya untuk membina di SDN 6 Bukit Tunggal.

Dinas Lingkungan Hidup (DLH) merupakan unsur pendukung pelaksanaan tugas Pemerintah Daerah di bidang pengelolaan lingkungan hidup, yang salah satu fungsinya adalah sebagai pemberi pelatihan, pembinaan, dan penghargaan dibidang lingkungan hidup.
Dinas Lingkungan Hidup Daerah mempunyai tugas melaksanakan penyusunan dan pelaksanaan kebijakan daerah bidang pengelolaan lingkungan hidup daerah." (Tupoksi Perangkat Daerah Dinas Lingkungan Hidup. 2009)

Kerja sama dengan SDN Percobaan bermula ketika SDN Percobaan mendapatkan program adiwiyata nasional dari Dinas Pendidikan Kota Palangka Raya, dimana sekolah harus membina sekolah-sekolah lain. Hal ini dibuktikan dengan adanya nota kesepahaman (memorandum of under-standing) Nomor: 420/79/Pend.IV/2014 tanggal 01 april 2014 antara SDN Percobaan dengan SDN 6 Bukit Tunggal. Hasil dari kerja sama SDN 6 Bukit Tunggal dan SDN 6 Percobaan yaitu sekarang SDN 6 Bukit Tunggal sudah menjadi salah satu sekolah yang peduli dengan kebersihan dan keindahan lingkungan sekolah, terbukti pada tahun 2015 SDN 6 Bukit Tunggal mendapatkan penghargaan berupa program adiwiyata dari Dinas Lingkungan Hidup Kota Palangka Raya. Hal tersebut diperkuat dengan keluarnya surat keputusan tim teknis pembinaan sekolah adiwiyata pada tanggal 12 Juni 2015, Nomor: $\quad$ 477/DLHK/Bid.I/VI/2015 tentang penetapan sekolah adiwiyata Kota Palangka Raya tahun 2015. Memutuskan: bahwa setelah tim penilai sekolah adiwiyata Kota Palangka Raya menyelenggarakan penilaian, survey dan verifikasi data ke beberapa sekolah di wilayah Kota Palangka Raya, pada hari kamis tanggal 10 juni 2015 sampai dengan hari jumat 12 juni 2015, maka sekolahsekolah yang menjadi sekolah adiwiyata Kota Palangka Raya tahun 2015 adalah salah satunya SDN 6 Bukit Tunggal Palangka Raya.

Selain menjalin kerja sama dengan SDN Percobaan, SDN 6 Bukit Tunggal juga bekerja sama dengan Dinas Lingkungan Hidup Kota Palangka Raya. Kerja sama ini bermula saat sekolah mendapatkan program adiwiyata. Kemudian Dinas Lingkungan Hidup Kota 
Palangka Raya ditunjuk untuk membina SDN 6 Bukit Tunggal. Kerja sama ini tidak menggunakan nota kesepahaman (memorandum of understanding) melainkan menggunakan surat keputusan tim teknis pembinaan sekolah adiwiyata pada tanggal 12 Juni 2015, Nomor: 477/DLHK/Bid.I/VI/2015 tentang penetapan sekolah adiwiyata Kota Palangka Raya tahun 2015.

Adapun yang dilakukan oleh Dinas Lingkungan Hidup di SDN 6 Bukit Tunggal yaitu, memberikan memotivasi dan mendorong agar tumbuhnya keinginan bersama untuk membuat lingkungan yang bersih dan hijau. Selain itu, bersama-sama dengan sekolah membuat program-program, seperti gotong royong/kerja bakti membersihkan selokan dan membuat drainase, penanaman pohon, pembuatan lahan terbuka hijau, pembuatan kebun sekolah, yang dilakukan oleh guru-guru, siswa, orang tua siswa, dan juga Dinas Lingkungan Hidup Kota Palangka Raya. Penyediaan tong sampah, sapu, dan bibit pohon serta terus membina dan memantau perkembangan sekolah oleh Dinas Lingkungan Hidup Kota Palangka Raya.

Adiwiyata merupakan sebuah program yang peduli dengan lingkungan yang sehat, bersih, serta lingkungan yang indah. Sedangkan program adiwiyata adalah salah satu program Kementrian Lingkungan Hidup dalam rangka mendorong terciptanya pengetahuan dan kesadaran warga sekolah dalam upaya pelestarian lingkungan hidup. Dalam program ini diharapakan setiap warga sekolah ikut terlibat dalam kegiatan sekolah menuju lingkungan yang sehat serta menghindari dampak lingkungan yang negatif.

Tujuan program adiwiyata yaitu menciptakan kondisi yang baik bagi sekolah dan menjadi tempat pembelajaran serta penyadaran warga sekolah seperti guru, murid, maupun orang tua siswa, sehingga di kemudian hari warga sekolah tersebut dapat turut bertanggung jawab dalam upaya-upaya penyelamatan lingkungan dan pembangunan berkelanjutan.

Hasil observasi peneliti tentang keadaan sekolah sekarang yaitu, lingkungan SDN 6 Palangka Raya bersih, hijau, dan terkelola dengan baik. Serta dibina terus-menerus oleh Dinas Lingkungan Hidup Kota Palangka Raya hingga sampai saat ini.

Berdasarkan asumsi dan uraian di atas yang membuat penulis tertarik untuk meneliti secara mendalam tentang bagaimana perencanaan, pelaksanaan, dan pengawasan dari hubungan kerja sama anatara sekolah dan Dinas Lingkungan Hidup Kota Palangka Raya, melalu sebuah penelitian yang berjudul "Kerja Sama Hubungan Masyarakat Sekolah Dasar Negeri 6 Bukit Tunggal Dengan Badan Lingkungan Hidup Kota Palangka Raya (studi kasus)"

\section{METODE}

Pendekatan yang digunakan pada penelitian ini adalah pendekatan kualitatif, karena ingin mengungkapkan dan mengkaji secara lebih mendalam pada kondisi yang alamiah tentang informasiinformasi mengenai Kerja Sama Hubungan Masyarakat Sekolah Dasar Negeri 6 Bukit Tunggal dengan Dinas Lingkungan Hidup Kota Palangka Raya. Metode Pengumpulan Data kualitatif dikumpulkan dari sumber data yang ada di lapangan, opini, perasaan, dan pengetahuan mereka yang diperoleh melalui wawancara. Metode pengumpulan data dilakukan dengan teknik: (1) Observasi, (2) Wawancara, (3) Dokumentasi, dan (4) Analisis Data. Analisis data dalam penelitian ini menggunakan analisis data menurut Miles and Huberman (dalam Sugiyono, 2013: 337). Komponen-komponen analisis data meliputi: (1) Reduksi Data, (2) Penyajian Data, (3) Menarik Kesimpulan. Langkah ketiga dari aktivitas analisis adalah menarik kesimpulan. Emzir (2014: 133) menyatakan "Dari permulaan pengumpulan data, penelitian kualitatif mulai memutuskan apakah 'makna' sesuatu, mencatat keteraturan, pola-pola, 
penjelasan, konfigurasi yang mungkin". Dalam penelitian ini peneliti hanya menggunakan dua dari keempat kriteria yaitu: (1) Kredibilitas, dan (2) Konfirmabilitas. Pengecekan kredibilitas data dilakukan melalui teknik: (1) Triangulasi, dan (2) Pengecekan anggota (member check).

\section{HASIL DAN PEMBAHASAN \\ Perencanaan Kerja Sama Hubungan Masyarakat Sekolah Dasar Negeri 6 Bukit Tunggal dengan Dinas Lingkungan Hidup Kota Palangka Raya}

Berdasarkan paparan data di atas diketahui bahwa perencanaan program yang dilakukan di Sekolah Dasar Negeri 6 Bukit Tunggal yaitu melalui tahapan seperti meninjau terlebih dahulu lokasi atau lingkungan sekolah, kemudian merumuskan tujuan yang jelas, setelah itu melakukan identifikasi data yang sesuai dengan program yang akan direncanakan, mencari pilihan pemecahan dari setiap masalah, menyusun keputusan dan langkah terakhir adalah melakukan penyusunan rencana kegiatan. Temuan penelitian tersebut di atas sesuai dengan pendapat yang dikemukan oleh Mulyono (2014: 26) bahwa "Proses perencanaan meliputi: (1) merumuskan tujuan yang jelas/operasional, (2) mengidentifikasi dan menganalisis data terkait dengan masalah, (3) mencari dan menganalisis alternatif pemecahan masalah, (4) mengomparasikan alternatif yang ditemukan, antara alternatif yang tepat guna, berhasil guna, dan praktis, (5) mengambil keputusan, dan (6) menyusun rencana kegiatan".

\section{Pelaksanaan Kerja Sama Hubungan Masyarakat Sekolah Dasar Negeri 6 Bukit Tunggal dengan Dinas Lingkungan Hidup Kota Palangka Raya}

Dari paparan data di atas diketahui bahwa pelaksanaan program kerja sama SD Negeri 6 Bukit Tunggal dengan Dinas Lingkungan Hidup Kota Palangka Raya sudah terjadwal, hal ini berguna untuk mempermudah dalam melaksanakan perencanaan yang sudah dibuat.
Pelaksanaan program ini dilakukan bersama-sama dengan orang tua siswa, Dinas Lingkungan Hidup, serta tenaga pendidik dan kependidikan yang ada di sekolah.

\section{Pengawasan Kerja Sama Hubungan Masyarakat Sekolah Dasar Negeri 6 Bukit Tunggal dengan Dinas Lingkungan Hidup Kota Palangka Raya}

Pengawasan merupakan fungsi manajemen yang tidak kalah penting dalam suatu organisasi. Semua fungsi terdahulu, tidak akan efektif tanpa disertai fungsi pengawasan. Berdasarkan paparan data di atas, pengawasan program dilakukan oleh Dinas Lingkungan Hidup Kota Palangka Raya dilakukan tiga bulan sekali. Sedangkan pengawasan yang dilakukan adalah melihat sejauh mana berjalannya program tersebut, jika ditemukan kekurangan maka akan dicari jalan keluarnya.

\section{SIMPULAN}

Berdasarkan hasil penelitian dan pembahasan yang telah diuraikan sebelumnya, dapat dirumuskan kesimpulan sebagai berikut:

1. Perencanaan kerja sama hubungan masyarakat Sekolah Dasar Negeri 6 Bukit Tunggal dengan Dinas Lingkungan Hidup Kota Palangka Raya. Dalam melakukan perencanaan terlebih dahulu mengamati keadaan lingkungan sekolah, merumuskan tujuan yang jelas, melakukan identifikasi data yang sesuai dengan program yang akan direncanakan, mencari pilihan pemecahan dari setiap masalah, menyusun keputusan dan langkah terakhir melakukan penyusunan rencana kegiatan. Adapun program yang direncanakan adalah gotong royong/kerja bakti membersihkan selokan dan membuat drainase, penanaman pohon, pembuatan lahan terbuka hijau, dan pembuatan kebun sekolah. 
2. Pelaksanaan kerja sama hubungan masyarakat Sekolah Dasar Negeri 6 Bukit Tunggal dengan Dinas Lingkungan Hidup Kota Palangka Raya. Untuk pelaksanaan program sudah terjadwal, seperti gotong royong/kerja bakti membersihkan selokan dan membuat drainase dilaksanakan setiap dua minggu sekali yaitu pada hari jumat. Sedangkan untuk penanaman pohon dilaksanakan seminggu sekali yaitu pada hari sabtu selama 1 bulan, pembuatan lahan terbuka hijau, pembuatan kebun sekolah dilaksanakan dua minggu sekali yaitu pada hari kamis.

3. Pengawasan kerja sama hubungan masyarakat Sekolah Dasar Negeri 6 Bukit Tunggal dengan Dinas Lingkungan Hidup Kota Palangka Raya. Pengawasan program dilakukan oleh Dinas Lingkungan Hidup Kota Palangka Raya tiga bulan sekali akan tetapi untuk jadwal atau hari tidak ditentukan. Sedangkan pengawasan yang dilakukan adalah melihat sejauh mana berjalannya program tersebut, jika ditemuka kekurangan maka akan dicari jalan keluarnya.

\section{UCAPAN TERIMAKASIH}

Ucapan terima kasih penulis sampaikan kepada pihak SDN 6 Bukit Tunggal yang telah memberikan ijin dan kemudahan proses memberikan ijin dan kemudahan proses selama berlangsungnya kegiatan penelitian, serta Redaksi Equity in Education Journal (EEJ) yang telah memberikan kesempatan artikel penulis dapat dimuat dalam jurnal ini.

\section{DAFTAR PUSTAKA}

Basrowi \& Suwandi. (2008). Memahami

Penelitian Kualitatif. Jakarta: Rineka Cipta.

Bintarto. (2016). Pengertian Lingkungan Hidup Menurut Para Ahli. Diunduh pada tanggal 11 mei 2018, dari www.spengetahuan.com/2016/03/

9-pengertian-lingkungan-hidup-

menurut-para-ahli.html.

Emzir. (2014). Metodologi Penelitian Kualitatif Analisis Data.Jakarta: PT RajaGrafindo Persada

Engkoswara., \& Komariah. A. (2012). Administrasi pendidikan. Bandung: Alpabeta

Fahrudin. (2012). Implementasi Manajemen Hubungan Sekolah Dengan Masyarakat dalam Pendidikan Sistem Ganda (Psg) Di SMTI Yogyakarta dan SMKN 4 Yogyakarta. Skripsi Sarjana, Universitas Negeri Yogyakarta, diunduh pada 17 Januari 2018, dari http://eprins.uny.ac.id.skripsi.hum as.fahrudin.

Fransiska, M. (2015). Peran Humas Dalam Membangun Citra Sekolah Menengah KejuruanBOPKRI 1 Yogyakarta.Skripsi Sarjana, Universitas Negeri Yogyakarta, diunduh pada 07 Januari 2018, dari http://eprins.uny.ac.id.skripsi.hum as.

Ismaya, B. (2015). Pengelolaan Pendidikan. Bandung: PT Refika Aditama

Moleong, L. J. (2012). Metodologi Penelitian Kualitatif. Bandung: Rosdakarya.

Mulyono. (2014). Manajemen Administrasi \& Organisasi Pendidikan. Jogjakarta: Ar-Ruzz Media

Nodyawati, E. (2011). Peran Humas Dalam Rangka Mempertahankan Reputasi Sekolah Favorit. Skripsi Sarjana, Universitas Sebelas Maret Surakarta. Diunduh pada tanggal 18 Januari 2018, dari http://eprints.uns.ac.id $>$ Unlock188791111201111421.pdf.

Program dan Kinerja Badan Lingkungan Hidup Provinsi Kalimantan Tengah. (2009). Diunduh pada tanggal 16 maret 2018, dari 
http://kalteng.go.id/ogi/viewarticl e.asp?ARTICLE id $=860$

Purwanto, M. N. (2009). Admisintrasi dan Supervisi Pendidikan. Bandung: PT Remaja Rosdakarya

Rahmad, A. (2016). Manajemen Humas Sekolah. Yogyakarta: Media Akademi.

Rahu, O. D. (2016). Manajemen Pendidikan dan Pelatihan Kurikulum 2013 Jenjang Sekolah Dasar di Lembaga Penjamin Mutu Pendidikan (LPMP) Provinsi Kalimantan Tengah. Skripsi Sarjana, tidak diterbitkan, Universitas Palangka Raya.

Rekysika, S. N. (2015). Upaya Meningkatkan Kemampuan Kerja Sama Melalui Kegiatan Kerja Kelompok Di Kelompok A TK Negeri Trukan Siwates Kaligintung Temon Kulon Progo. Skripsi Sarjana, Universitas Negeri Yogyakarta. Diunduh pada tanggal 18 Januari 2018, dari http://eprints.uny.ac.id $>$ nola $>$ sand a $>$ rekysika.

Reniningsih, E. (2011). Peningkatan Kemampuan Kerjasama Siswa Melalui Group Investigation Pada Mata Pelajaran Pengolahan Makanan Kontinental Di Smk Sahid Surakarta. Skripsi Sarjana, Universitas Negeri Yogyakarta. Diunduh pada 02 Mei 2018, dari https://eprints.uny.ac.id $>$ erida $>$ ren iningsih.

Sagala, S. (2013). Administrasi Pendidikan Kontemporer. Bandung: Alfabeta

Saifil, A. (2017). Peran Humas Dalam Mempromosikan SMKN $1 \mathrm{Al}$ Mubarkeya Ingin Jaya Aceh Besar. Skripsi Sarjana, Universitas Islam Negeri Ar-Raniry Banda Aceh. Diunduh pada 18 Januari 2018, dari https://repository.arraniry.ac.id.skripsi.humas.ahmad. saifil

Sugiyono. (2013). Metode Penelitian Pendidikan (Pendekatan Kuantitatif, Kualitatif, dan R \& D). Bandung: Alfabeta.

Suryosubroto. (2012). Hubungan Sekolah Dengan Masyarakat (School Public Relations). Jakarta: PT Rineka Cipta.

Tugas Pokok Badan Lingkungan Hidup. (2015). Diunduh pada 11 mei 2018, dari https://dlh.banglikab.go.id $>$ profil $>$ tugas.

Undang-Undang Nomor 20 Tahun 2003 tentang Sistem Pendidikan Nasional.

Yusuf, M. (2016). Metode Penelitian Kuantitatif, Kualitatif, \& Penelitian Gabungan. Jakarta: Prenadamedia Group. 